\title{
Random or clumped: How litter dwelling scorpions are distributed in a fragment of Brazilian Atlantic forest
}

\author{
Gabriela Cavalcanti Silva de Gusmão Santos ${ }^{1}$, Welton DionisiO-dA-Silva ${ }^{2}$, João Pedro SOUZA-AlVeS ${ }^{2}$, \\ Cleide Maria Ribeiro de AlbUQUERQUE ${ }^{1}$ and André Felipe de Araujo LiRA ${ }^{1, *}$ \\ ${ }^{1}$ Departamento de Zoologia, Universidade Federal de Pernambuco, Rua Prof. Moraes Rego S/N, Cidade Universitária, \\ CEP 50570-420, Recife, Brazil; e-mails: gaabigusmao@outlook.com, cleide.ufpe@gmail.com \\ 2 Programa de Pós-Graduação em Biologia Animal, Departamento de Zoologia, Universidade Federal de Pernambuco, \\ Rua Prof. Moraes Rego S/N, Cidade Universitária, CEP 50570-420, Recife, Brazil; e-mails: weltonxdc@gmail.com, \\ souzaalves1982@gmail.com, andref.lira@gmail.com
}

Key words. Scorpiones, Ananteris mauryi, Tityus (Archaeotityus) pusillus, Payandeh aggregation index, population ecology, spatial distribution, rainforest, Brazil

\begin{abstract}
Knowledge of the patterns in the spatial distribution of species provides valuable information about the factors (resources and environment) that regulate the use of space by animals. Typically, the distribution of litter-dwelling scorpions in Atlantic forests is correlated with the structure of their microhabitats, although to better understand their natural history more studies on the patterns in their use of space are required. Therefore, we investigated the effect of rainfall on the patterns in the spatial distributions and population densities of two sympatric species of scorpion, Tityus (Archaeotityus) pusillus Pocock 1893 and Ananteris mauryi Lourenço 1982 in a fragment of Atlantic Forest in Brazil. The study was carried out during the dry (September) and rainy (June) months. We collected 501 individuals (268 T. (A.) pusillus and 233 A. mauryi) by actively searching at night using UV lanterns. We found that the spatial distribution and population density of $T$. (A.) pusillus, but not $A$. mauryi, were significantly affected by rainfall, with $T$. (A.) pusillus individuals showing a clumped pattern during the rainy month and random distribution in the dry month. We also found a different response in the population densities of the two species, with $T$. (A.) pusillus but not $A$. mauryi being affected by rainfall. Our results indicate that, although co-habiting in leaf litter, these species respond differently to rainfall, which affects their spatial distribution and abundance in this habitat.
\end{abstract}

\section{INTRODUCTION}

How individuals in a population are distributed in their respective habitats (i.e., species distribution) can be determined either at the species-level (e.g., among different species) or at the population level (e.g., among populations of the same species) (Rodrigues et al., 2010; Arbab et al., 2014; Sujithra \& Chander, 2016). Within a habitat, availability of resources (e.g., shelter, food) and environmental factors (e.g., dry and rainy periods) are likely to influence the distributions of species (Eterovick \& Barata, 2006; Leal et al., 2016; Lira et al., 2018a). In addition, the presence of conspecifics and other species in the environment can result in competition for resources and can affect a species' habitat selection (Dufour et al., 2015; Lira \& DeSouza, 2016; Salomão et al., 2016). For example, the distribution of litter-dwelling scorpions in Atlantic Forests in Brazil are positively correlated with the dry mass of leaf litter and layer use within the litter (Lira et al., 2013, 2015). Knowledge of the distribution of populations of a species is extremely important for a better understanding of population dynamics and the main factors that determine the persistence of organisms in natural environments (Patil \& Stiteler, 1973). Specifically, scorpions are ecologically important because of their strong potential effect on community dynamics and structure, especially due to arthropod predation (Polis, 1990; Polis \& Yamashita, 1991).

In the Atlantic Forest in Brazil, the litter-dwelling scorpions, Tityus (Archaeotityus) pusillus Pocock 1893 and Ananteris mauryi Lourenço 1982 share the same microhabitat (epi-leaf litter) only during the rainy season, most likely due to the flooding of the lower litter layers (Lira et al., 2013). During the dry season, these species use different layers of leaf litter and so avoid intraguild competition; $T$. (A.) pusillus inhabits the epi-leaf litter (approximately 2-3 cm thick, composed of fallen whole leaves and twigs) and $A$. mauryi inhabits the sub-leaf litter $(3-4 \mathrm{~cm}$ thick composed of pieces of leaves in different stages of decomposition) (Lira et al., 2013). However, there is no information on the horizontal distribution of species of Neotropical scorpions. Most studies on the aggregation patterns of invertebrates in forest soil focus on groups other than arachnids (Verhoef \& van Selm, 1983; Thomas et al., 2001; Grear \& Schmitz, 2005) and studies involving scorpions in Neotropical wet forests are rare (e.g. Dias et al., 2006; Yamaguti \& Pinto da Rocha, 2006; Lira \& DeSouza, 2014; Ott \& Ott, 2014). For example, the Brazilian Atlantic Forest is a

\footnotetext{
* Corresponding author; e-mail: andref.lira@gmail.com
} 
biodiversity hotspot (Myers et al., 2000), currently with only $11 \%$ to $16 \%$ of its original forest cover remaining (Ribeiro et al., 2009). Within this forest, there is an average of three and six species in scorpion assemblages, which vary in species richness depending on the size of the forest remnant (Lira et al., 2016, 2018b).

Here, we evaluated the spatial distribution of two sympatric scorpion species, $T$. (A.) pusillus (body length 25-34 mm) and $A$. mauryi (body length $25 \mathrm{~mm}$ ) (Lourenço, 1982, 2002) in a large fragment of Atlantic Forest in the Northeastern part of Brazil and assessed whether their population sizes were sensitive to rainfall. Specifically, we were interested in how $T$. (A.) pusillus and $A$. mauryi are distributed in the leaf litter and how extrinsic factors, such as rainfall, affect their distribution and abundance. We hypothesized that due to A. mauryi's active hunting strategy and dependence on moisture, this species would show a clumped distribution in the dry months, when individuals seek more humid sites (Lira et al., 2013; Lourenço, 2015), and a random distribution in the rainy months. In contrast, the distribution of $T$. (A.) pusillus, a more sedentary species (Lira et al., 2013), will not be affected by rainfall because it is less dependent on moisture and avoids expending energy dispersing.

\section{MATERIALS AND METHODS}

This study was carried out in a large fragment of Atlantic Forest (7,324 ha) at the Campo de Instrução Marechal Newton Cavalcanti (CIMNC) in the municipality of Abreu e Lima ( $7^{\circ} 46^{\prime} 55^{\prime \prime} \mathrm{S}$, $\left.35^{\circ} 09^{\prime} 02^{\prime \prime} \mathrm{W}\right)$. This area has been undergoing natural regeneration since it was occupied by the military in 1944. The site used for this study is at an interface between evergreen and semi-deciduous forests, dominated by herbaceous vegetation, shrubs and canopy trees, such as Cyperaceae, Poaceae, Gentianaceae, Solanaceae, Fabaceae, Boraginaceae, Malvaceae, and Rubiaceae, with average heights of 7-10 $\mathrm{m}$ and diameters of $20 \mathrm{~cm}$ (Lucena, 2009).

Scorpions were collected during the month with the lowest precipitation (September 2016, with total rainfall of $11 \mathrm{~mm}$ ) and the month with the highest precipitation (June 2016, with total rainfall of $220 \mathrm{~mm}$ ) (APAC, 2016). To study the spatial distribution of the scorpions, six $20 \times 10 \mathrm{~m}$ quadrats were randomly distributed and spaced $20 \mathrm{~m}$ apart. The quadrats were visited once during each month (The total area sampled was $1,200 \mathrm{~m}^{2}$ each month). The quadrats were established at least $200 \mathrm{~m}$ from the forest edge in order to avoid edge effects. In each quadrat, the central point (CP) was georeferenced with a handheld GPS Garmin Etrex Vista HCx. Active nocturnal search (19:00-23:00 h) was undertaken by three experienced researchers (GCSGS, WDS and AFAL) equipped with UV lamps. The sampling effort per quadrat was 45 min, resulting in a total effort of $9 \mathrm{~h}$. All the scorpions that were seen within the quadrats were manually collected using tweezers. We used UV lamps because scorpions glow under UV radiation and can be observed directly in their microhabitat, thus increasing the sampling efficiency (Honetschlager, 1965; Polis, 1990). During the sampling, the distance of each scorpion collected from the CP was measured and recorded. All scorpions collected were preserved in $70 \%$ ethanol and identified by procedures described in Lourenço (2002). Voucher specimens of $T$. (A.) pusillus and A. mauryi were deposited in the Arachnological Collection at the Universidade Federal de Pernambuco, Recife, Brazil.

The assessment of the spatial distributions of the scorpions was based on the Payandeh's Index of Aggregation (PIA), where the variance in the scorpion's distance from the $\mathrm{CP}$ is divided by the mean (Payandeh, 1970). According to the PIA, values between 0 and 1 indicate uniform distributions, between 1 and 1.5 indicate random distributions and $>1.5$ indicate a clumped distribution. Population density was calculated by dividing the number of scorpions collected in each quadrat by the quadrat area $\left(200 \mathrm{~m}^{2}\right)$. A Student's t-test was used to verify whether the mean values for density and the PIA for each of the two scorpion species varied between months. In order to obtain a point estimator for PIA and population density for each month, we calculated the mean \pm standard deviation for each quadrat. We used a Student's t-test to compare the mean PIA obtained with the thresholds defined by the index. Also, we bootstrapped the mean of PIA and population density for each month using 9,999 randomizations to generate its $99 \%$ confidence intervals. This was done because there was no spatio-temporal replication and to strengthen our data analysis. We used the boot and plotrix packages (Canty \& Ripley, 2017; Lemon et al., 2018) for this. All the statistical analyses were performed using the R software v. 3.5.0 (R Core Team, 2018).

\section{RESULTS}

A total of 501 scorpions were collected during this study (Fig. 1). In the dry month, more on average of $T$. (A.) pusillus were collected $(27.17 \pm 18.36)$ than of $A$. mauryi $(20.50 \pm 4.42)$. In contrast, during the rainy season the mean abundance of $A$. mau$r y i$ was slightly higher $(18.33 \pm 4.97)$ than that of $T$. (A.) pusillus $(17.50 \pm 8.43)$. Of the total collected, 268 individuals belonged to $T$. (A.) pusillus and 233 to A. mauryi (Fig. 1). Tityus (A.) pusillus distinctly differed in the pattern of its distribution between months, with a clumped distribution in the rainy month (PIA = $2.54 \pm 0.85$ ) and a random distribution in the dry month (PIA $=$ $1.40 \pm 0.80$ ). In contrast, the pattern of distribution of $A$. mauryi was aggregated in both the rainy (PIA $=2.00 \pm 0.80)$ and dry (PIA $=2.30 \pm 1.30$ ) months. Except for the mean PIA for $T$. (A.) pusillus in the dry month $(\mathrm{t}=29.00, \mathrm{df}=1, \mathrm{p}=0.02)$, the other mean PIA values were not significantly different from the thresholds of the index $[T$. (A.) pusillus: rainy month: $\mathrm{t}=3.88, \mathrm{df}=1, \mathrm{p}=0.16$; A. mauryi: dry month: $\mathrm{t}=4.75, \mathrm{df}=1, \mathrm{p}=0.13$; rainy month: $\mathrm{t}$ $=7.00, \mathrm{df}=1, \mathrm{p}=0.09$ ]. Significant differences in aggregation indices were recorded between months for $T$. $($ A.) pusillus $(\mathrm{t}=$ $2.33, \mathrm{df}=10, \mathrm{p}=0.04)$, but not $A$. mauryi $(\mathrm{t}=-0.40, \mathrm{df}=10, \mathrm{p}$ $=0.69$ ) (Fig. 1). Although both species were most abundant in the dry month, with an increase of $21.6 \%$ and $5.6 \%$ for $T$. (A.) pusillus and $A$. mauryi, respectively (Table 1), the difference was not significant $[T$. (A.) pusillus: $\mathrm{t}=-1.08, \mathrm{df}=10, \mathrm{p}=0.30 ; A$. mauryi: $\mathrm{t}=-0.86, \mathrm{df}=10, \mathrm{p}=0.40]$. However, the overlap of the

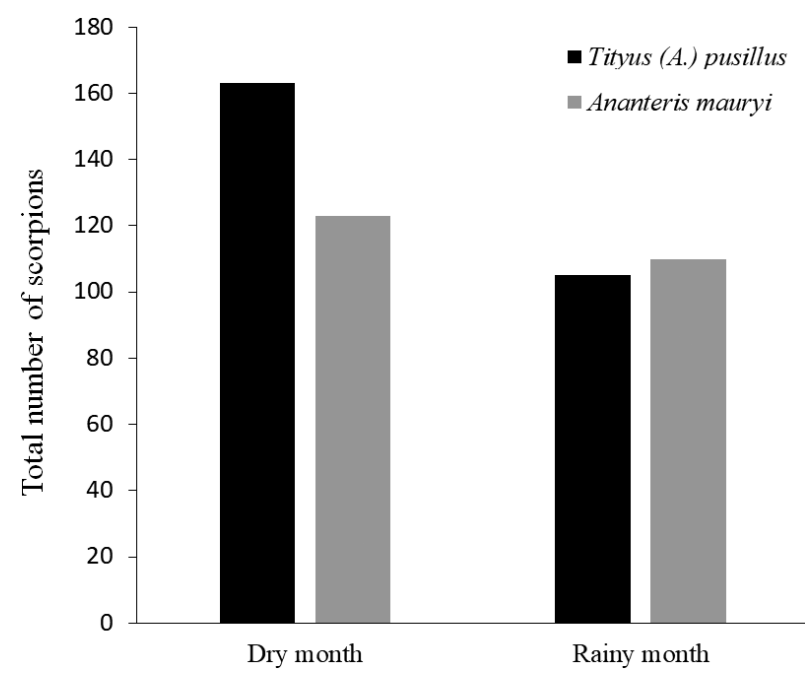

Fig. 1. Numbers of Tityus (A.) pusillus and Ananteris mauryi collected in a fragment of the Atlantic Forest in the northeast of Brazil during the dry and rainy months. 
A Tityus (A.) pusillus
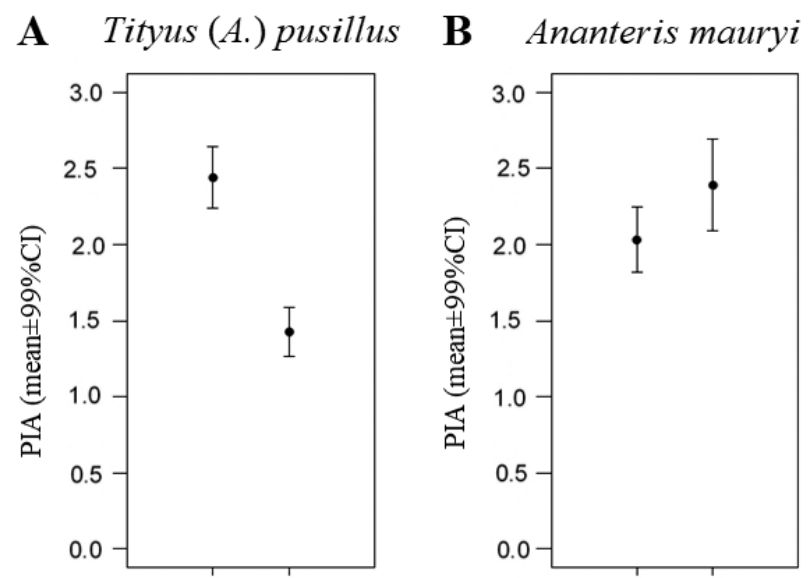

C

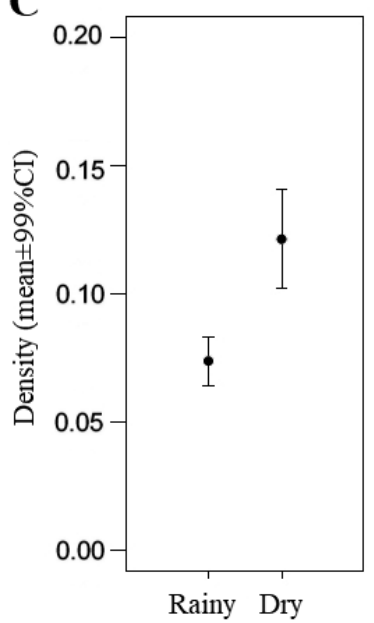

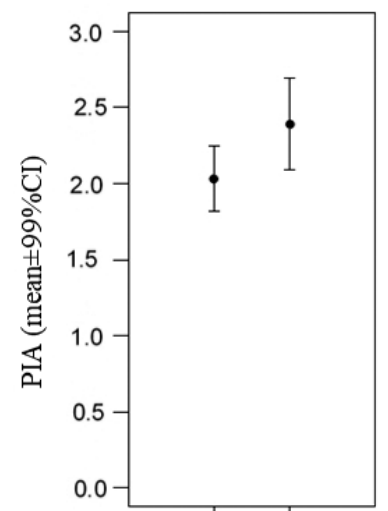

D

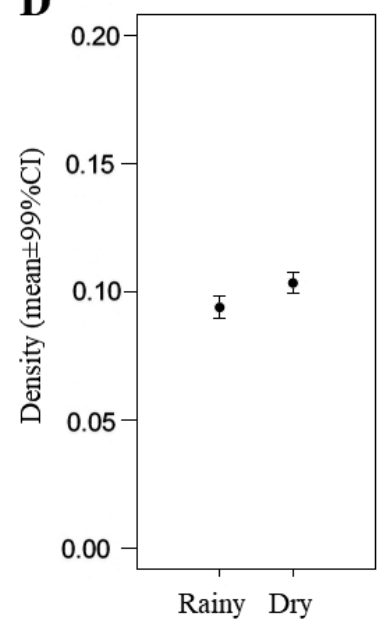

Fig. 2. Mean and $99 \%$ confidence intervals of the Payandeh Index of Aggregation (PIA) and numbers $/ \mathrm{m}^{2}$ of Tityus (A.) pusillus (A, C) and Ananteris mauryi $(B, D)$ in a fragment of Atlantic Forest in the northeast of Brazil during the dry and rainy months.

confidence intervals for the mean population density of $T$. (A.) pusillus indicate that it could be significantly different between the dry and rainy months (Fig. 2).

\section{DISCUSSION}

In the current study, we analyzed the horizontal distributions and population densities of two co-occurring litter-dwelling species of scorpion, T. (A.) pusillus and A. mauryi, in a fragment of Brazilian Atlantic Forest and investigated how rainfall can effect these parameters. Contrary to our hypothesis, we found a non-random pattern of spatial distribution for these species, with

only $T$. (A.) pusillus being distributed randomly during the rainy month, when an increase in the density of this scorpion was also noted.

Changes in the spatial distribution associated with rainfall may be related to alterations in habitat structure. According to a previous study carried out in a fragment of Atlantic Forest, litter fall is significantly higher during the dry months than during the rainy months (Schessl et al., 2008). Thus, the seasonal litter fall may result in substantial increases in habitat heterogeneity for scorpions, thus influencing their spatial distribution through their use of new habitats for shelter and predation (Polis \& McCormick, 1987; McReynolds, 2007).

The differences in the use of microhabitats and their predatory behaviour may also play an important role in the differences in the aggregation patterns of $T$. (A.) pusillus and A. mauryi. Tityus (A.) pusillus is a sit-and-wait predator that inhabits the upper layers of the leaf litter (Lira et al., 2013, 2018a). Generalist predators are usually found in habitats where they are more likely to encounter prey and in which the incidences of cannibalism and intraguild predation are low (Schmidt \& Rypstra, 2010). The higher amount of leaf litter due to the increase in litter fall during the dry season (Schessl et al., 2008) is likely to affect only the top layer of litter (Sampaio et al., 1993), which is preferred by T. (A.) pusillus. Possibly, this change in the top layer of litter reduces intraguild predation and cannibalism in $T$. (A.) pusillus due to an increase in the availability of shelter, allowing them to colonize a larger area, thereby resulting in a random distribution. In contrast, $A$. mauryi is an active forager that is frequently found in the lower litter layers (Lira et al., 2013). During the dry season the lower litter layers are less affected by litter fall, so the structure of these layers remains unchanged (Sampaio et al., 1993) and their complexity also remains unchanged. Because species in the genus Ananteris are humicolous (Lourenço, 2010, 2015), it is possible that the search for more humid locations also contributes to the clumped distribution of this species in the dry month.

During the rainy month, the distributions of both $T$. (A.) pusillus and $A$. mauryi were clumped. During this time, the increase in humidity and decrease in litter fall (Schessl et al., 2008) may result in compaction of the leaf litter and consequently a reduction in the availability of shelter for litter-dwelling arthropods such as $T$. (A.) pusillus and A. mauryi. The limitations on the availability of shelter, caused by flooding, are likely to promote the relocation of individuals to drier areas, thus explaining the clumped pattern found for both species during this season. Studying the vertical distribution of T. (A.) pusillus and A. mauryi in a similar environment, Lira et al. (2013) also report a difference in distribution, with both species colonizing the upper leaf litter layers during rainy months and the upper and lower leaf litter layers are colonized by $T$. (A.) pusillus and $A$. mauryi, respectively, during dry months. In addition, a study by Zinner \& Amitai (1969) demon-

Table 1. Payandeh Index of Aggregation (PIA) and population density (individuals $/ \mathrm{m}^{2}$ ) of Tityus (A.) pusillus and Ananteris mauryi during dry and rainy months in a remnant of Brazilian Atlantic forest. Values between 0 and 1 indicate uniform distribution, between $1<1.5$ indicate random distribution and $>1.5$ indicate a clumped distribution.

\begin{tabular}{|c|c|c|c|c|c|c|c|c|}
\hline \multirow{3}{*}{ Quadrat } & \multicolumn{4}{|c|}{ Dry month } & \multicolumn{4}{|c|}{ Rainy month } \\
\hline & \multicolumn{2}{|c|}{ Tityus (A.) pusillus } & \multicolumn{2}{|c|}{ Ananteris mauryi } & \multicolumn{2}{|c|}{ Tityus $(A$.$) pusillus$} & \multicolumn{2}{|c|}{ Ananteris mauryi } \\
\hline & PIA & Density & PIA & Density & PIA & Density & $\mathrm{PIA}$ & Density \\
\hline Q1 & 0.44 & 0.04 & 2.56 & 0.09 & 1.59 & 0.05 & 2.15 & 0.05 \\
\hline Q2 & 1.08 & 0.08 & 1.75 & 0.08 & 2.72 & 0.14 & 2.87 & 0.08 \\
\hline Q3 & 1.99 & 0.08 & 2.11 & 0.12 & 2.34 & 0.12 & 1.36 & 0.13 \\
\hline Q4 & 2.72 & 0.10 & 0.92 & 0.13 & 1.82 & 0.05 & 1.07 & 0.10 \\
\hline Q5 & 1.19 & 0.28 & 4.79 & 0.09 & 3.97 & 0.05 & 3.18 & 0.08 \\
\hline Q6 & 1.00 & 0.21 & 1.59 & 0.09 & 2.83 & 0.11 & 1.44 & 0.09 \\
\hline Mean \pm SD & $1.40 \pm 0.80$ & $0.13 \pm 0.09$ & $2.3 \pm 1.30$ & $0.10 \pm 0.02$ & $2.54 \pm 0.80$ & $0.08 \pm 0.04$ & $2.00 \pm 0.80$ & $0.09 \pm 0.02$ \\
\hline
\end{tabular}


strates that Compsobuthus acutecarinatus (Simon, 1882) and C. schmiedeknechti Vachon 1949 migrate to higher places to build their burrows during the rainy season in Israel.

We found that the density of $T$. (A.) pusillus, but not A. mauryi, was affected by rainfall. Other studies on scorpion density report a reduction in population density during the rainy season. For instance, a reduction in the population size of Centruroides vittatus (Say, 1821) at Arkansas, USA, is associated with its incapacity to dig burrows to mitigate the effects of climate, exposing it to freezing winter temperatures and harsh environmental factors (Yamashita, 2004). It is reported that the increase in the density of the fossorial scorpion, Hoffmannihadrurus gertschi (Soleglad, 1976) (Quijano-Ravell et al., 2012) during the rainy season in deciduous tropical forest in Mexico may be associated with the dispersal of young, despite the lack of changes in their surface activity throughout the year (Quijano-Ravell et al., 2011).

In addition, the change in the pattern of distribution from being clumped in the rainy month and randomly distributed in the dry month, along with the increase in density recorded for $T$. (A.) pusillus matches the beginning of the reproductive season of the species. According to Dionisio-da-Silva et al. (2018) the reproductive season of this scorpion is from October to January and peaks in November. Males increase their foraging activity, and consequently their surface activity during the breeding season (Polis, 1990). Further, their surface activity increases when they search for females to mate. This may have affected the pattern of spatial distribution and density of $T$. (A.) pusillus in the dry month. In contrast, the reproductive period of $A$. mauryi is in the rainy season (Dionisio-da-Silva et al., 2018), but they have a clumped distribution and similar densities during the dry and rainy month, indicating that for this species, their distribution could be more associated with environmental features than reproductive activity. Small animals are more susceptible than large ones to water loss, since they have a larger surface relative to their body mass (Lourenço, 2015) and can increase their survival by moving, either vertically or horizontally, to microsites that have high moisture levels during periods of drought (Hagvar, 1983; Verhoef \& Van Selm, 1983).

Overall, our study indicates that environmental factors at a microhabitat scale and species interactions may play an important role in the distribution, but not the density of the leaf litterdwelling scorpions T. (A.) pusillus and A. mauryi in the Brazilian Atlantic Forest. Differences related to hunting behaviour (sit-andwait or wandering) and species-specific features may explain the different responses in terms of spatial distribution to variation in rainfall found in $T$. (A.) pusillus and A. mauryi. Finally, in order to obtain more robust results, future research should include a greater number of quadrats randomly distributed in the area, as well as, sampling in various months in the dry and rainy seasons. Also, we recommend that other biotic and abiotic variables such as air temperature, humidity, depth and dry mass of leaf litter be measured in order to obtain a better understanding of the spatial pattern and density of scorpions.

ACKNOWLEDGEMENTS. We are very grateful to the military command of the Campo de Instrução Marechal Newton Cavalcanti (CIMNC) for permission to use the area to collect samples. We are also grateful to Coordenação de Aperfeiçoamento de Pessoal de Nivel Superior (CAPES) for the doctoral scholarshop to AFAL, Conselho Nacional de Desenvolvimento Científico e Tecnológico $(\mathrm{CNPq})$ for a research productivity funding (Fellowship \#307759/2015-6) to CMRA and to Fundação de Amparo à Ciência e Tecnologia de Pernambuco (FACEPE) for master scholarship to WDS. JPSA was supported by PNPD/CAPES (Process no. 527091) and FACEPE (BCT-0025-2.05/17). We are most grate- ful to A. DeSouza for their comments on an earlier draft of the manuscript. We are also extremely grateful to the editor and two anonymous reviewers for valuable comments on the manuscript and suggestions for the statistical analysis.

\section{REFERENCES}

APAC 2016: Agência Pernambucana de Águas e Clima. URL: http://www.apac.pe.gov.br/meteorologia/ (last accessed 16 May 2016).

ARBAB A. 2014: Spatial distribution and minimum sample size for overwintering larvae of the rice stem borer Chilo suppressalis (Walker) in Paddy Fields. - Neotrop. Entomol. 43: 415-420.

Canty A. \& Ripley B. 2017: Boot: Bootstrap R (S-Plus) Functions. R Packages Version 1.3-20. URL: https://cran.r-project. org/web/packages/boot/.

Dias S.C., Candido D.M. \& Brescovit A.D. 2016: Scorpions from Mata do Buraquinho, João Pessoa, Paraíba, Brazil, with ecological notes on a population of Ananteris mauryi Lourenço (Scorpiones, Buthidae). - Rev. Bras. Zool. 176: 707-710.

Dionisio-DA-Silva W., LiRa A.F.A. \& Albuquerque C.M.R. 2018: Distinct edge effects and reproductive periods of sympatric litter-dwelling scorpions (Arachnida: Scorpiones) in a Brazilian Atlantic forest. - Zoology 129(4): 17-24.

Dufour C.M.S., Meynard C., Watson J., Rioux C., Benhamou S., Perez J., Avenant J.J.N., Pillay N. \& Ganem G. 2015: Space use variation in co-occurring sister species: response to environmental variation or competition? - PLOS ONE 10(2): e0117750, 15 pp.

Eterovick P.C. \& Barata I.M. 2006: Distribution of tadpoles within and among Brazilian streams: the influence of predators, habitat size and heterogeneity. - Herpetologica 62: 365-377.

Grear J.S. \& Schmitz O.J. 2005: Effects of grouping behavior and predators on the spatial distribution of a forest floor arthropod. - Ecology 86: 960-971.

Hagvar S. 1983: Collembola in Norwegian coniferous forest soils II. Vertical distribution. - Pedobiologia 25: 383-401.

HONETSCHLAGER L.D. 1965: A new method for hunting scorpions. - Turtox News 43: 69-70.

Leal C.R.O., Silva J.O., Sousa-Souto L. \& de Siqueira Neves F. 2016: Vegetation structure determines insect herbivore diversity in seasonally dry tropical forests. - J. Insect Conserv. 20: 979-988.

LENOM J. 2006: Plotrix: a package in the red light district of R. R-News 6(4): 8-12.

LiRA A.F.A. \& DeSouza A.M. 2014: Microhabitat use by scorpion species (Arachnida: Scorpiones) in the montane Atlantic Rain Forest, Brazil. — Iber. J. Arachnol. 24: 107-108.

Lira A.F.A. \& DeSouza A.M. 2016: Microhabitat use of harvestmen (Arachnida: Opiliones) assemblage in the highland Brazilian Atlantic rainforest. - Can. J. Zool. 94: 323-327.

Lira A.F.A., Souza A.M., Silva Filho A.A. \& Albuquerque C.M.R. 2013: Spatio-temporal microhabitat use by two cooccurring species of scorpions in Atlantic rainforest in Brazil. —Zoology 116: 182-185.

Lira A.F.A., Rego F.N.A.A. \& Albuquerque, C.M.R. 2015: How important are environmental factors for the population structure of co-occurring scorpions species in tropical forest? Can. J. Zool. 93: 15-19.

Lira A.F.A., Araújo V.L.N., DeSouza A.M., Rego F.N.A.A. \& AlbuQuerque C.M.R. 2016: The effect of habitat fragmentation on the scorpion assemblage of a Brazilian Atlantic Forest. - J. Insect Conserv. 20: 457-466.

Lira A.F.A., DeSouza A.M. \& Albuquerque C.M.R. 2018a: Environmental variation and seasonal changes as determinants of 
the spatial distribution of scorpion (Arachnida: Scorpiones) in Neotropical forests. - Can. J. Zool. https://doi.org/10.1139/ cjz-2017-0251.

Lira A.F.A., Damasceno E.M., Silva-Filho A.A.C. \& AlbuquerQUE C.M.R. 2018b: Linking scorpion (Arachnida: Scorpiones) assemblage with fragment restoration in the Brazilian Atlantic Forest. - Stud. Neotrop. Fauna Environ. 53: 107-112.

LOURENÇO W.R. 1982: Révision du genre Ananteris Thorell, 1891 (Scorpiones, Buthidae) et description de six espèces nouvelles. - Bull. Mus. Natl. Hist. Nat. Paris 4e sér 4(A1/2): 119-151.

Lourenço W.R. 2002: Scorpions of Brazil. Editions de l'If, Paris, $308 \mathrm{pp}$.

LOURENÇO W.R. 2010: The disrupted pattern of distribuition of the genus Hadrurochactas Pocock; evidence of past connctions between Amazonan the Brazilian Atlantic Forest. - C. R. Biol. 333: $41-47$.

Lourenço W.R. 2015: Comments on the Ananterinae Pocock, 1990 (Scorpiones: Buthidae) and description of a new remarkable species of Ananteris from Peru. - C. R. Biol. 338: 134139.

LuCena M.F.A. 2009: Flora da Mata do CIMNC, Pernambuco, Brasil. Apoio a Criação de Unidades de Conservação na Floresta Atlântica de Pernambuco, Recife, 18 pp.

McReynolds C.N. 2008: Microhabitat preferences for the errant scorpion, Centruroides vittatus (Scorpiones, Buthidae). $-J$. Arachnol. 36: 557-564.

Myers N., Mittermeier R.A., Mittermeier C.G., Fonseca G.A.B. \& Kent J. 2000: Biodiversity hotspots for conservation priorities. - Nature 403: 853-858.

Отт R. \& Отт A.P. 2014: Abundance and seasonality of Bothriurus signatus (Arachnida, Scorpiones) in different vegetal formations in São Francisco de Paula, RS, Brazil. — Iheringia 104: 92-98.

Patil G. \& Stiteler W. 1974: Concepts of aggregation and their quantification: A critical review with some new results and applications. - Res. Pop. Ecol. 15: 238-254.

PAYANDEH B. 1970: Comparison of method for assessing spacial distribution of trees. - Forest Sci. 16: 312-317.

Polis G.A. 1990: The Biology of Scorpions. Standford University Press, Standford, $587 \mathrm{pp}$.

Polis G.A. \& McCormick S.J. 1987: Intraguild predation and competition among species of desert scorpions. - Ecology 68 : 332-343.

Polis G.A. \& Yamashita T. 1991: The ecology and importance of predaceous arthropods in desert communities. In Polis G.A. (ed.): The Ecology of Desert Communities. University of Arizona Press, Tucson, pp. 180-222.

Quijano-Ravell A.F., Ponce-Saavedra J. \& Francke O.F. 2011: Ciclo de vida de Hadrurus gertschi Soleglad (Scorpiones: Iuridae) en una localidad del Estado de Guerrero, Mexico. - Iber. J. Zool. 19: 133-145.
Quijano-Ravell A.F., Ponce-Saavedra J. \& Francke O.F. 2012: Densidad, distribución espacial y biomasa de Hadrurus gertschi Soleglad (Scorpiones: Iuridae) en una localidad de Guerrero, Mexico. - Iber. J. Arachnol. 20: 35-43.

R Core Team 2018: $R$ : A Language and Environment for Statistical Computing. R Foundation for Statistical Computing, Vienna. URL: https://www.R-project.org/.

Ribeiro M.C., Metzger J.P., Martensen A.C., Ponzoni F. \& HiROTA M.M. 2009: Brazilian Atlantic Forest: how much is left and how the remaining Forest distributed? Implications for conservation. - Biol. Conserv. 142: 1141-1153.

Rodrigues T.R., Fernandes M.G. \& Santos H.R. 2010: Distribuição espacial de Aphis gossypii (Glover) (Hemiptera, Aphididae) e Bemisia tabaci (Gennadius) biótipo B (Hemiptera, Aleyrodidae) em algodoeiro Bt e não-Bt. - Rev. Bras. Entomol. 54: 136-143.

Salomão R.P., LiRa A.F.A. \& Costa F.C. 2016: Records of perching by dung beetles (Coleoptera: Scarabaeidae: Scarabaeinae) in the Northeastern Atlantic Forest of Brazil. - Coleopt. Bull. 70: 903-906.

Sampaio E.V.S.B., Dall'Olio A., Nunes K.S. \& Lemos E.E.P. 1993: A model of litterfall, litter layer losses and mass transfer in a humid tropical forest at Pernambuco, Brazil. $-J$. Trop. Ecol. 9: 291-301.

Schessl M., Da Silva W.L. \& GotTsberger G. 2008: Effects of fragmentation on forest structure and litter dynamics in Atlantic rainforest in Pernambuco, Brazil. - Flora 203: 215-228.

SCHMidT J.M. \& RYPSTRA A.L. 2010: Opportunistic predator prefers habitat complexity that exposes prey while reducing cannibalism and intraguild encounters. - Oecologia 164: 899-910.

SujtThra M. \& Chander S. 2016: Distribution pattern and sequential sampling plan for spotted pod borer, Maruca vitrata (Fabricius) (Lepidoptera: Crambidae) on pigeon pea, Cajanus cajan L. - Int. J. Pest Manag. 62: 64-68.

Thomas C.F.G., Parkinson L., Griffiths G.J.K., Garcia A.F. \& Marshall E.J.P. 2001: Aggregation and temporal stability of carabid beetle distributions in field and hedgerow habitats. J. Appl. Ecol. 38: 100-116.

Verhoef H.A. \& Selm A.V. 1983: Distribution and population dynamics of Collembola in relation to soil moisture. - Ecography 6: 387-388.

Yamaguti H.Y. \& Pinto-DA-Rocha R. 2006: The ecology of Thestylus aurantiurus of the parque estadual da Serra da Cantareira, São Paulo, Brazil (Scorpiones, Bothriuridae). - J. Arachnol. 34: 214-220.

YAMASHITA T. 2004: Surface activity, biomass, and phenology of striped scorpion, Centruroides vittatus (Buthidae) in Arkansas. - Euscorpius 17: 25-33.

ZiNNER H. \& AMitai P. 1969: Observations on hibernation of Compsobuthus acutecarinatus E. sin. and C. schmiedeknichti Vachon (Scorpionidea, Arachnida) in Israel. — Isr. J. Zool. 18: 41-47.

Received January 30, 2018; revised and accepted August 14, 2018 Published online August 28, 2018 